\title{
Hepatita A, o patologie amenințătoare de viață la copiii mici cu boală Wilson - prezentare de caz
}

\author{
Cristian Dan Mărginean¹, Nicoleta Tomşa², Bianca Aron², Daniela Ciobanu², \\ Lorena Elena Meliț 1,2
}

${ }^{1}$ Universitatea de Medicină, Farmacie, Ştiinţe şi Tehnologie „G.E. Palade“, Tg. Mureş, România

${ }^{2}$ Clinica Pediatrie, Spitalul Clinic Judeţean de Urgenţă, Tg. Mureş, România

\begin{abstract}
REZUMAT
Introducere. Hepatita A este cea mai frecventă cauză de hepatită acută la copii. Boala Wilson (BW) este o patologie autozomal recesivă rară care poate duce la hepatopatie cronică. Hepatita A poate reprezenta un trigger pentru debutul BW.

Prezentare de caz. Prezentăm cazul unei paciente în vârstă de 7 ani, fără antecedente personale patologice semnificative, internată în clinica noastră pentru hemoragie digestivă superioară, icter și distensie abdominală. Debutul bolii a fost cu 1 lună anterior internării când a fost diagnosticată cu hepatită A. Analizele de laborator la momentul internării au arătat anemie, reactanți de fază acută pozitivi, hiperbilirubinemie directă, citoliză hepatică, nivel seric crescut al fosfatazei alcaline, hiponatremie și coagulopatie severă. Ecografia abdominală a pus în evidență hepatomegalie, ecostructură hepatică inomogenă, ecogenitate granulară, cu micronoduli, diametrul venei porte de $9 \mathrm{~mm}$, pulsatilitate alterată a venei porte, splenomegalie și ascită. Endoscopia digestivă superioară a arătat hiperemie și edem la nivelul mucoasei gastrice, cu cheaguri aderente la suprafața mucoasei și varice incipiente la nivelul fornixului gastric. Ecocardiografia a evidentiat colectie pleurală și pericardică în cantitate mică. Am exclus hepatita B și C, toxoplasma, rubeola, herpes virus, virusul Epstein Barr, citomegalovirusul și hepatita autoimună. Pe baza nivelurilor scăzute ale ceruloplasminei și cuprului seric, asociate cu testul pozitiv la D-penicilamină, împreună cu varicele gastrice și hipertensiunea portală, am stabilit diagnosticul de BW. Consultul oftalmologic și cel neurologic au fost în relații normale. Evoluția clinică și cea paraclinică a pacientei au fost favorabile după inițierea terapiei chelatoare.

Concluzii. Cu toate că este rară, asocierea dintre hepatita A și BW poate duce la insuficiență hepatică acută și deces, în special la copiii fără antecedente patologice.
\end{abstract}

Cuvinte cheie: hepatită A, boală Wilson, ciroză hepatică, copil, insuficiență hepatică acută

$\begin{array}{ll}\text { Abrevieri } & \\ \text { Alb - albumină } & \mathrm{Hb} \text { - hemoglobină } \\ \mathrm{ALT} \text { - alanin-aminotransferază } & \mathrm{Htc}-\text { hematocrit } \\ \mathrm{APh} \text { - fosfatază alcalină } & \mathrm{INR}-\text { international normalized ratio } \\ \mathrm{AST} \text { - aspartat-aminotransferază } & \mathrm{Na}-\text { sodiu } \\ \mathrm{PCR} \text { - proteina C reactivă } & \mathrm{BiT}-\text { bilirubină } \\ \mathrm{BiD} \text { - bilirubina directă } & \mathrm{BW}-\text { boală Wilson }\end{array}$

VSH - viteza de sedimentare a eritrocitelor

\section{INTRODUCERE}

Hepatita A este o patologie răspândită în întreaga lume, fiind cea mai comună cauză de hepatită acută la copii [1]. Virusul hepatitic de tip A este un picornavi- rus ARN și nu duce la hepatopatie cronică, fiind transmis pe cale fecal-orală [2]. Cu toate că incidența variază în funcție de zona geografică, fiind legată de condițiile sanitare, nivelul socio-economic, igienă și 
vaccinare, aproximativ 10 milioane de indivizi sunt diagnosticați în fiecare an cu hepatită de tip A $[3,4]$. Astfel, în zonele endemice, incidența poate ajunge la 150 de cazuri la 100.000 în fiecare an [5]. În ciuda faptului că este autolimitantă, ratele de morbiditate și mortalitate ale hepatitei A rămân importante, ducând la o rată de deces de $0,2 \%$ [6]. Evoluția clinică variază de la status asimptomatic la insuficiență hepatică fulminantă în funcție de vârstă, iar majoritatea cazurilor la vârsta pediatrică rămân nediagnosticate din cauza lipsei simptomelor sau simptomatologiei nespecifice [7]. Simptomele inițiale includ greață, vărsături, anorexie, febră moderată, scădere ponderală, oboseală, artralgii și mialgii, definind faza anicterică, ce poate dura până la 7 zile [8]. Această fază este urmată de cea icterică, exprimată prin urină de culoare închisă și materii fecale deschise la culoare. În timpul acestei faze, doar $10 \%$ dintre copiii sub vârsta de 6 ani vor prezenta icter, $40 \%$ dintre cei cu vârsta între 6 și 14 ani și $70 \%$ peste 14 ani, comparativ cu adulți, la care apare în până la $85 \%$ dintre cazuri [8]. În forma tipică de hepatită A, simptomele menționate anterior pot dura câteva săptămâni, cu o medie de 4 săptămâni, iar infecția se rezolvă, de obicei, spontan, cu sechele minime [9]. Diagnosticul este stabilit pe detectarea anticorpilor IgM anti-virus hepatitic A, niveluri crescute ale transaminazelor, bilitubina totală (BiT), bilirubina directă (BiD), albumina, proteinele totale, hemoleucograma și coagulograma [9]. Cu toate acestea, simptomele atipice de hepatită A au fost, de asemenea, raportate atunci când anticorpii de tip IgM pot persista până la 6-12 luni și pot fi asociaţi cu alte patologii, cum ar fi hepatita autoimună, tulburările complexe imune, hepatita colestatică, hepatita recurentă și altele $[8,9]$. Mai mult, hepatita A poate fi un trigger atât pentru debutul hepatitei autoimune, cât și al BW $[8,10]$. Cazurile necomplicate de hepatită necesită doar tratament suportiv, transplantul hepatic fiind necesar doar în 3-8\% dintre cazurile în care apare insuficiența hepatică fulminantă [9]. Programele naționale de vaccinare sunt esențiale pentru scăderea ratelor de morbiditate și mortalitate asociate hepatitei A.

BW sau degenerescența hepatolenticulară a fost descrisă pentru prima dată în 1912 de Samuel Alexander Kinnier-Wilson ca fiind o patologie neurologică definită prin degenerescența lenticulară progresivă a creierului asociată cu ciroză hepatică [11]. Este o patologie autozomal recesivă cu o frecvență scăzută, de aproximativ 1 la 30.000 de indivizi [12]. Debutul comun al BW este în timpul copilăriei timpurii până în perioada de adult tânăr, cu un peak în jurul vârstei de 17 ani [13]. Pacienții care prezintă iniţial simptome hepatice prezintă debutul mai devreme comparativ cu cei care au simptome neurologice [14]. Prezentarea neurologică este definită prin dizartrie, distonie, mers anormal, tremor, parkinsonism, coree, atetoză și convulsii [13]. Pe de altă parte, manifestările hepatice asociate cu BW cuprind hepatită acută, insuficiență hepatică fulminantă, hepatită cronică activă și ciroză [13]. Inelul Kayser-Fleischer apare în cazul depozitelor de cupru la nivelul zonei limbice a corneei și este patognomonic pentru BW [13]. Alte semne şi simptome pot apărea la pacienții cu BW, precum afectarea renală, litiază biliară, osteoporoză, osteomalacie, artrită, oligomenoree sau amenoree, miocardită, anomalii electrocardiografice, hipertensiune ortostatică, afectare pancreatică, tegumentară sau paratiroidiană [13]. Diagnosticul biochimic al BW include ceruloplasmină scăzută, cupru urinar bazal crescut pe 24 de ore, concentrație hepatică crescută de cupru, dozarea cuprului seric putând fi utilă, de asemenea, în diagnosticarea acestor pacienţi [15]. Testarea genetică pentru detectarea genei ATP7B este efectuată doar în cazurile în care diagnosticul este incert. Tratamentul BW trebuie efectuat pe durata întregii vieți și vizează tratamentul supraîncărcării cu cupru, incluzând următoarele medicamente: D-penicilamină, trietilentetramin hidroclorid, zinc, tetratiomolibdat și dimercaprol. Abilitățile de comunicare ale medicului sunt esențiale pentru monitorizarea adecvată a acestor pacienți [16].

Scopul acestei prezentări de caz este de a sublinia că hepatita A poate declanșa debutul cirozei hepatice secundare BW la un copil nediagnosticat anterior.

Consimțământul informat a fost obținut de la mama pacientei anterior publicării acestui caz.

\section{PREZENTARE DE CAZ}

\section{Motivele internării}

Prezentăm cazul unei paciente în vârsta de 7 ani, fără antecedente personale patologice cunoscute, internată în clinica noastră pentru hemoragie digestivă superioară, icter și distensie abdominală. Debutul bolii a fost cu aproximativ 1 lună anterior internării în clinica noastră, când a fost diagnosticată cu hepatită A, ulterior fiind trimisă în clinica noastră pentru persistența icterului și hemoragie digestivă superioară de aproximativ 1 săptămână. 


\section{Examen obiectiv}

Examenul clinic la momentul internării a evidențiat stare generală influenţată, icter intens la nivelul tegumentelor şi mucoaselor, edeme palpebrale și la nivelul membrelor inferioare, abdomen destins, sensibil la palpare, hepatomegalie (ficat la $2 \mathrm{~cm}$ sub rebordul costal drept) și splenomegalie (splina la $3 \mathrm{~cm}$ sub rebordul costal stâng). Greutatea pacientei a fost de $23 \mathrm{~kg}$.

\section{Elemente de diagnostic și evaluare}

Analizele de laborator la momentul internării au pus în evidență anemie (Hb 7,6 g/dl, Htc 23,2\%), markeri inflamatori crescuți (PCR 13,61 mg/l, VSH 30 $\mathrm{mm} / \mathrm{h}$ ), hiperbilirubinemie directă (BiT 11,959 mg/dl, BiD 10,131 mg/dl), hipoalbuminemie (Alb 2,5 g/dl), hepatocitoliză (AST 204,1 U/1, ALT 103,7 U/1), fosfatază alcalină crescută (APh 660 U/l), și hiponatremie (Na $134 \mathrm{mmol} / \mathrm{l})$. Pacienta a asociat, de asemenea, coagulopatie (INR 4,1). Ecografia abdominală a arătat hepatomegalie, ecostructură neomogenă, ecogenitate granulară, diametrul venei porte de $9 \mathrm{~mm}$, pulsatilitatea venei porte alterată, splenomegalie și ascită. Endoscopia digestivă superioară arată hiperemie și edem la nivelul mucoasei gastrice, cheaguri aderente, varice incipiente la nivelul fornixului gastric GOV I. Ecocardiografia a arătat colecție pleurală și pericardică în cantitate mică. Am exclus infecțiile virale, precum hepatita B și C, toxoplasma, rubeola, virusul herpetic, virusul Epstein Barr, citomegalovirusul, dar și hepatita autoimună. Am identificat niveluri scăzute ale ceruloplasminei $(0,135 \mathrm{~g} / \mathrm{l})$ şi ale cuprului seric $(55,58 \mu \mathrm{g} /$ dl), dar cuprul urinar a fost în limite normale $(22,47$ $\mu \mathrm{g} / 24 \mathrm{~h}$ ). Consultul oftalmologic și neurologic au fost în limite normale. Pe baza tuturor celor menţionate anterior, am ridicat suspiciunea de BW asociată cu insuficiență hepatică acută, hipertensiune portală și varice la nivelul fornixului gastric.

\section{Management terapeutic și evaluare}

Am administrat substituţie cu albumină umană și masă eritrocitară, diuretice (Furosemid), aminoacizi intravenos, vitamina $\mathrm{K}$, antibiotice și am inițiat tratament cu betablocanți neselectivi (Propranolol) și D-penicilamină.

\section{Monitorizare și urmărire}

Evoluția pacientei a fost favorabilă după inițierea tratamentului menționat anterior, fără semne de he- moragie digestivă superioară, cu remiterea ascitei, a colecțiilor pleurale și pericardice după aproximativ 1 lună şi normalizarea fluxului la nivelul venei porte. Mai mult, parametrii coagulogramei s-au ameliorat considerabil (INR 1,49), precum și nivelurile bilirubinei (BiT 4,438 mg/dl, BiD 3,366 mg/dl). După aproximativ 24 de ore, am repetat ceruloplasmina pentru a exclude o posibilă valoarea fals pozitivă din cauza hipoalbuminemiei și cuprul urinar. Astfel, nivelul ceruloplasminei a rămas scăzut $(0,197 \mathrm{~g} / \mathrm{l})$, iar valoarea cuprului urinar s-a dublat $(42,15 \mu \mathrm{g} / 24 \mathrm{~h})$, susținând diagnosticul de BW declanșată de hepatita A.

\section{DISCUȚII}

Focarele comunitare de hepatită sunt comune în zonele endemice, cum ar fi țările subdezvoltate sau în curs de dezvoltare din cauza condițiilor sanitare și de igienă improprii. $\mathrm{Cu}$ toate acestea, în România, mai ales în județul Mureş, am observat un focar de hepatită A din septembrie 2018 până în ianuarie 2019. Pacienta noastră a fost diagnosticată cu hepatită A pe baza serologiei pozitive în această perioadă. Este bine cunoscut faptul că hepatita A este autolimitantă și mai mult de 70\% dintre copiii cu vârsta sub 6 ani sunt asimptomatici [17]. De asemenea, până la $20 \%$ dintre cei peste această vârstă prezintă simptome [17]. Pacienta noastră a prezentat simptome gastrointestinale, dar, după remiterea lor, ea a început să manifeste simptome de ciroză.

Insuficiența hepatică acută este o patologie rară la copii, cu rată mare de mortalitate. Definiția insuficienței hepatice acute, conform Grupului de Insuficiență Hepatică Acută Pediatrică, implică următoarele condiții: lipsa unei dovezi de hepatopatie cronică diagnosticată anterior, dovadă biochimică de injurie hepatică acută şi coagulopatie hepatică exprimată printr-un timp prelungit al protrombinei $\geq 15$ secunde sau INR $\geq 1,5$ necorectat de suplimentarea cu vitamina $K$, asociat semnelor clinice de encefalopatie sau timp al protrombinei $\geq 20$ secunde sau INR $\geq 2,0$ independent de prezența sau absența encefalopatiei [18]. Un studiu recent efectuat pe copiii cu hepatopatie acută a subliniat că encefalopatia hepatică clinică este rară la vârstele pediatrice comparativ cu adulții [19]. Mai mult, același studiu a arătat că BW a fost a doua cea mai frecventă cauză de insuficiență hepatică acută la copii, afectând 16 pacienți, urmată de hepatita A, 14 pacienți [19]. Pacienta noastră a 
îndeplinit criteriile menționate anterior pentru insuficiența hepatică acută, dat fiind faptul că nu a avut hepatopatii diagnosticate anterior, a avut analize biochimice ce au dovedit hepatopatie acută și, cu toate că nu a avut semne de encefalopatie hepatică, INR-ul ei la momentul internării în clinica noastră a fost 4,1 . Din fericire, coagulopatia a răspuns foarte bine la terapia cu vitamina $\mathrm{K}$. Cel mai probabil, atât hepatita $\mathrm{A}$, cât și BW au contribuit la dezvoltarea insuficienței hepatice în cazul pacientei noastre, dar identificarea varicelor gastrice și aspectul micronodular al ficatului la ecografie susțin perioada cronică subiacentă nediagnosticată anterior, frecvent întâlnită la pacienții cu BW înaintea diagnosticului. Acelaşi studiu menționat anterior a stabilit o clasificare a pacienților în trei grupe de risc, după cum urmează: grupa I, cuprinzând pacienți cu nivel al BiT $<5,35 \mathrm{mg} / \mathrm{dl}$ și INR $<3,66$ (sau PT $<23,5$ secunde), grupa II pentru nivel al BiT $>5,35 \mathrm{mg} / \mathrm{dl}$ sau INR $>3,66$ (sau PT $>23.5$ secunde), și grupa III în cazul pacienților cu nivel al $\mathrm{BiT}>5,35$ $\mathrm{mg} / \mathrm{dl}$ și INR $>3,66$ (sau PT $>23,5$ secunde) [19]. Autorii au arătat că 37 dintre cei 38 de pacienți incluși în grupa III au decedat [19]. Conform clasificării menționate anterior, pacienta noastră poate fi clasificată ca având risc crescut, aparținând grupei III. $\mathrm{Cu}$ toate acestea, evoluția ei a fost neașteptat de favorabilă după iniţierea suplimentării cu vitamina $\mathrm{K}$ și a tratamentului suportiv. Mai mult, după inițierea terapiei cu D-penicilamină, nivelul Bi a scăzut $<5 \mathrm{mg} / \mathrm{dl}$, iar INR-ul $<1,5$.

Injuriile acute, precum hepatita virală A sau ingestia anumitor droguri și toxine, sunt trigerri bine cunoscuți ai decompensării unui pacient cu boală hepatică cronică. Datele publicate în literatură referitoare la această asociere la copii sunt limitate. Astfel,

\section{BIBLIOGRAFIE}

1. Acharya SK, Batra $Y$, Bhatkal B, et al. Seroepidemiology of hepatitis A virus infection among school children in Delhi and north Indian patients with chronic liver disease: implications for HAV vaccination. $J$ Gastroenterol Hepatol. 2003;18(7):822-827.

2. Brundage SC, Fitzpatrick AN. Hepatitis A. Am Fam Physician. 2006; 73(12):2162-2168

3. Jacobsen $\mathrm{KH}$, Wiersma ST. Hepatitis A virus seroprevalence by age and world region, 1990 and 2005. Vaccine. 2010;28(41):6653-6657.

4. Bell B, Anderson D, Feinstone S. Principles and practice of infectious diseases. In Mandell GL, Bennett JE, Dolin R, editors. Hepatitis A Virus; Philadelphia: Elsevier, 2005; pp. 2162-2185.

5. Kumar KJ, Kumar HC, Manjunath VG, Anitha C, Mamatha S. Hepatitis A in children- clinical course, complications and laboratory profile. Indian J Pediatr. 2014;81(1):15-19.

6. Mauss S, Berg T, Rockstroh J. Hepatology: A clinical textbook. Druckerei Heinrich $\mathrm{GmbH}, 2016$; pp. 31-47. studiul lui Jagadisan şi colab. a demonstrat că suprainfecția cu virusurile A, B și E la copiii cunoscuți sau necunoscuți anterior cu hepatopatie cronică poate duce la insuficiență hepatică acută [20]. Mai mult, autorii au demonstrat că BW și hepatita autoimună au fost cele mai frecvente cauze de hepatopatie cronică manifestate clinic pentru prima dată cu insuficiență hepatică [20]. Dintre cei 10 pacienți diagnosticaţi cu BW în studiul lor, doar 3 au supraviețuit [20]. Pacienții care s-au vindecat după injuria acută sunt consideraţi a avea prognostic bun pe termen lung [20]. În ciuda prognosticului nefavorabil iniţial, pacienta noastră s-a vindecat după injuria acută produsă de suprainfecția cu hepatita $\mathrm{A}$, având o evoluție clinică și biochimică favorabilă. Mai mult, datorită iniţierii terapiei chelatoare, cel mai probabil, prognosticul ei pe termen lung se va îmbunătăţi considerabil. Özçay şi colab. au raportat un caz similar de hepatită A ca trigger al injuriei hepatice acute la o pacientă de 7 ani necunoscută anterior cu BW, dar pacienta lor a decedat în a 12-a zi de internare [21]. Din fericire, pacienta noastră a avut evoluție favorabilă după vindecarea hepatitei A. Rareori, BW se poate asocia și cu hepatita autoimună [22]. În cazul nostru, serologia pentru hepatita autoimună a fost negativă.

\section{CONCLUZII}

Insuficiența hepatică acută nu este frecventă la copii, dar este asociată cu rate mari de mortalitate. Debutul simptomelor la copiii nediagnosticați cu BW poate fi declanşat de hepatita A. Astfel, cazul nostru susține nevoia unui program național de vaccinare pentru a preveni decesul consecutiv insuficienței hepatice acute la această grupă de pacienți.

Conflict of interest: none declared Financial support: none declared

7. Girish N, Sunil B, Devaranavadagi R. A clinical study of viral hepatitis in children: A prospective hospital-based study. Int J Contemp Pediatr. 2018;5:563-8.

8. Chakravarty R, Chowdhury A, Chaudhuri S, et al. Hepatitis B infection in Eastern Indian families: need for screening of adult siblings and mothers of adult index cases. Public Health. 2005; 119(7):647-654.

9. Rook M, Rosenthal P. Hepatitis A in children. In Jonas MM. Viral Hepatitis in Children; London: Humana Press, 2010; pp. 1-12.

10. Committee on Infectious Diseases; American Academy of Pediatrics; Kimberlin DW, Brady MT, Mary Anne Jackson MA, Long SS. Hepatitis C. In Red Book; 2009; pp. 357-60.

11. Compston A. Progressive lenticular degeneration: A familial nervous disease associated with cirrhosis of the liver, by S. A. Kinnier Wilson, (From the National Hospital, and the Laboratory of the National 
Hospital, Queen Square, London) Brain 1912;34:295-509. Brain . 2009;132:1997-2001.

12. Hahn SH. Population screening for Wilson's disease. Ann N Y Acad Sci. 2014;1315:64-69.

13. Lorincz M. Wilson disease and related copper disorders. Handbook of Clinical Neurology, Vol. 147 (3rd series) Neurogenetics, Part I. Geschwind DH, Paulson HL, Klein C (editors). Elsevier, 2018.

14. Merle U, Schaefer M, Ferenci P, Stremmel W. Clinical presentation, diagnosis and long-term outcome of Wilson's disease: A cohort study. Gut. 2007;56(1):115-120.

15. Müller T, Tanner S. Disorders of Copper Metabolism. In Diseases of the Liver and Biliary System in Children, Kelly DA (ed.). John Wiley \& Sons LTD, 2017; pp. 323-339.

16. Mărginean $\mathrm{CO}$, Meliţ LE, Chinceşan $\mathrm{M}$, et al. Communication skills in pediatrics - the relationship between pediatrician and child. Medicine (Baltimore). 2017;96(43):e8399.
17. Jeong SH, Lee HS. Hepatitis A: clinical manifestations and management. Intervirology. 2010;53(1):15-19.

18. Bucuvalas J, Yazigi N, Squires RH Jr. Acute liver failure in children. Clin Liver Dis. 2006;10(1):149-vii.

19. Bariş Z, Saltik Temızel IN, Uslu N, et al. Acute liver failure in children: 20-year experience. Turk J Gastroenterol. 2012;23(2):127-134.

20. Jagadisan B, Srivastava A, Yachha SK, Poddar U. Acute on chronic liver disease in children from the developing world: recognition and prognosis. J Pediatr Gastroenterol Nutr. 2012;54(1):77-82.

21. Ozçay F, Canan O, Akcan B, Bilezikçi B. Hepatitis A super infection as a cause of liver failure in a child with Wilson's disease. Turk $J$ Pediatr. 2007;49(2):199-202.

22. Dara N, Imanzadeh F, Sayyari AA, Nasri P, Hosseini AH. Simultaneous Presentation of Wilson's Disease and Autoimmune Hepatitis; A Case Report and Review of Literature. Hepat Mon. 2015; 15(6):e29043. 